\title{
Water Shortage Management at Letaba Water Catchment Area in Limpopo Province, of South Africa
}

\author{
Dr Matshidiso Kanjere \\ Ms Kgomotlokoa Thaba \\ Mr Magapu Lekoana
}

University of Limpopo

\section{Doi:10.5901/mjss.2014.v5n27p1356}

\begin{abstract}
Water shortages have been experienced in many parts of the world and more so in Africa. Many households have been negatively affected by lack of access to clean water. Water scarcity affects many spheres of living such as agricultural, economic, environmental, industrial and social spheres. Hence, water management issues have been on the top agenda of many governments and policy makers around the globe as the scarcity of this essential commodity is aggravated by global warming. It is against this background that an empirical investigation was conducted at Letaba catchment area. The purpose of the investigation was to evaluate the efficiency of water management strategies put in place at Letaba catchment area. The mixed-methods research approach was used, namely qualitative and quantitative. The researchers conducted the interviews with the relevant government officials. Questionnaires were also distributed to validate the information gathered through the interviews. One of the research findings was that strategies used to manage water shortages were ineffective and that communities around were not consulted when water management policies were developed. Thus, literature and legislation relevant to the phenomena were reviewed. The research recommended that local communities should be consulted whenever water management strategies and policies are developed.
\end{abstract}

Keywords: Water management, water scarcity, water catchment and water management strategies

\section{Introduction}

Water is becoming a scarce resource over time, requiring a re-look at the water management approach. Edna Molewa the Minister of Water and Environmental Affairs in South Africa (2013:1) states that the challenge of managing water resources requires proactive solutions, especially with the reality of climate change on our doorstep. Over the years increasing urbanization, industrialization, increased irrigated agriculture, and rising population have resulted in increased demand for water. There are several ways of defining water scarcity. In general, water scarcity is defined as the point at which the aggregate impact of all users impinges on the supply or quality of water under prevailing institutional arrangements to the extent that the demand by all sectors, including the environment, cannot be satisfied fully (Global Water Partnership, 2000:3). Water scarcity is a relative concept and can occur at any level of supply or demand. Scarcity may be a social construct such as being a product of affluence, expectations and customary behaviour or the consequence of altered supply patterns. Water scarcity has various causes, most capable of being remedied or alleviated (Global Water Partnership, 2000:3).

Water scarcity is often experienced in the arid and semi-arid regions affected by droughts and wide climate variability. In some areas water scarcity is caused by a combination of high population growth and economic development whereby water consumption increases. Symptoms of water scarcity include severe environmental degradation including river desiccation and pollution, declining groundwater levels, and increasing problems of water allocation where some groups win at the expense of others. The Department of Water Affairs (2014) state that human settlement, agricultural production and tourism between Drakensburg escarpment and the Kruger National Park have placed demands on the water resources of the Groot Letaba River which can no longer be met within reasonable risks of shortages from the existing infrastructure.

Water scarcity requires a change in the water management paradigm so that the demand can be met. The Department of Water Affairs (2014) maintains that water management strategies have to be reassessed so as to find solutions on how best water supply can be managed. Water as an essential commodity has to be used more efficiently 
among existing and potential users; it has to be managed according to economic principles. Comprehensive Assessment of Water Management in Agriculture reveals that one in three people today face water shortages. Around 1.2 billion people, or almost one-fifth of the world's population, live in areas of physical scarcity, and 500 million people are approaching this situation. Another 1.6 billion people, or almost one quarter of the world's population, face economic water shortage (Comprehensive Assessment of Water Management in Agriculture, 2007:10)

This article draws attention to some of the specific causes of water scarcity problems in Letaba catchment and draws attention to the social, economic and health risks that these pose for society. Smits (2005) maintains that water plays an important role in people's livelihoods. It is therefore vitally important to ensure that water is used economically and that at the same time municipalities make water accessible to all the people. Without sufficient water of suitable quality, we will not be able to achieve a just, equitable and sustainable future for our people. This will have equally bleak prospects for our neighbours as well.

Some of water scarcity problems experienced in this era came about as a result of the legacy of high industrialized and population growth. It is only now that the effects of not taking care of the natural resources and water in particular are felt. Thus, a study was conducted at Letaba water catchment to determine the management of water in the area and strategies that can be developed to take care of this special commodity.

\section{Problems and Effects of Water Scarcity}

Water resource at Letaba catchment is steadily becoming a scarce resource, major water sources are drying up, and there is increased pressure and demand on the available water resources. Goba Moahloli Keeva Steyn (Pty) Ltd (2004) state that water requirements in the Letaba catchment has exceeded the available resource and the catchment as a whole is in deficit. Competing demands for water use are for domestic use, water for economic development, water for industrial use, environmental, agricultural and in the process there is pollution of water resources. Van Vuuren (2009:31) mentions some problems on water as being decreasing quality of water, water scarcity, dysfunctional municipal water infrastructures that have resulted in the potential water crisis widely publicized in the media. Generally, the South African water sector faces numerous challenges such as increased water deficits, water pollution and decreasing water quality that not only affect availability of water and impact negatively on human health (Machete, 2011:4).

Stone (2009: 46) also observed that the other problem with water shortage is that South African municipalities find it difficult to move water pipes over long distances. They find it costly to transport water from the dams or rivers to sustain industries and households because reservoirs are not conveniently located. In April 2008 South African Institution of Civil Engineering (SAICE) council meeting, raised this question: "Are we facing a water crisis similar to the energy crisis?" The Water Division took up the challenge of addressing this question. Several discussions with key role players confirmed that there are indeed a number of challenges that can be described no other way than as crises that need to be met with great urgency (Herold, 2009:1).

\section{Letaba Catchment Area}

The study was conducted at Letaba catchment area to evaluate the efficiency of water management strategies in the area. The area comprises of the water resources of the catchment of the Luvuvhu, Mutale, Letaba and Shingwedzi rivers linked to adjacent systems as indicated by the inter-basin transfers on Figure 1.1. The Letaba water management area is located in the north-eastern corner of South Africa, where it borders on Zimbabwe in the north and on Mozambique along the eastern side. It falls entirely within the Limpopo Province, and adjoins the Olifants and Limpopo water management areas to the south and west respectively. The Letaba water management area forms part of the Limpopo River Basin, and internationaly the river is shared by South Africa, Botswana, Zimbabwe and Mozambique (refer to Fig.1). 


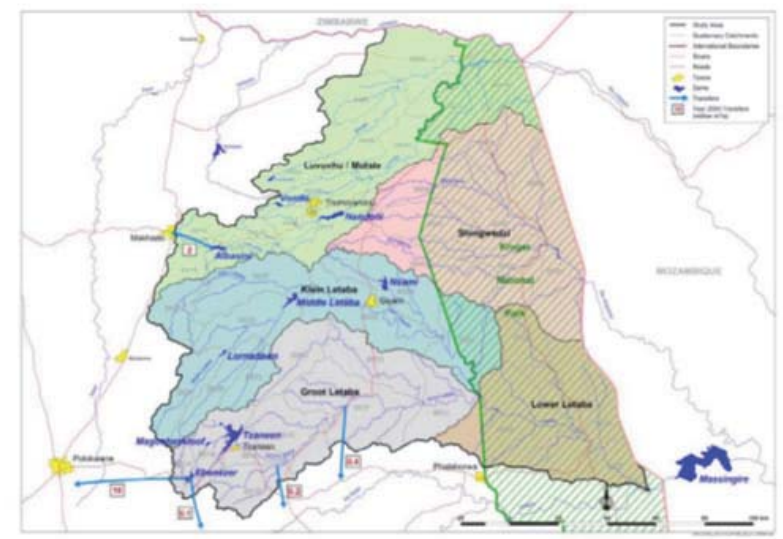

Figure 1-Study Area

http://www.dwaf.gov.za/rdm/documents/Briefing\%20Document.pdf

\section{Population}

The population that reside in Letaba catchment is evenly distributed across the urban, rural and informal settlements. Bless, Higson-Smith and Kagee (2006:98) define population as the entire set of objects or people, which is the focus of the research and about which the researcher wants to determine some characteristics. Some 1535000 people (1995 population which is about $3.5 \%$ of the country's total) reside in the Luvuvhu/Letaba water management area (DWAF: 2003).

More than $90 \%$ of the population is rural based, with most living in informal rural villages and settlements. The population is relatively evenly distributed throughout the region and the density is comparatively high for rural areas. Very few people live in the Kruger National Park. Most of the urban population is found in Tzaneen, Nkowakowa, Thohoyandou and Giyani, which are the main urban centres (Internal strategic perspective: Luvuvhu/Letaba water management area 2004).

The research focused on the Department of Water Affairs at Mopani District in Limpopo.

\section{Research Methodology}

A mixed methods research approach was used, that is both qualitative and quantitative research approaches were used, with more emphasis on qualitative design. Data collected through the qualitative method was complemented by data collected through the quantitative method. Leedy and Ormrod (2014: 269) maintain that quantitative aspects of the study can compensate for weaknesses in qualitative research, and vice versa. Qualitative data was collected through the interviews. Quantitative data was collected through questionnaires. Twenty officials from the Department of Water Affairs participated in the study. This is because the study focused on the management of water in Letaba area and thus managers responsible for the area were interviewed. Ten managers were exposed to unstructured interviews and the other ten completed the questionnaires.

\section{Findings}

- There is a high competition in the area over water; water in the area is accessible to high income residents and poor communities do not have access to clean water.

- Poor households fetch water from unsafe sources.

- A lot of water is lost in the system through leaking pipes and pipes that burst from time to time due to poor management and old infrastructure.

- Illegal connections account for a large percentage of stolen water.

- Agricultural farmers in the area use more water than it is allocated to them.

- Limited human resources capacity account for inadequate planning for technical operations.

- Water management policies are developed without the consultation of the communities. 
- Limited education is given to communities on water saving strategies.

\section{Discussions}

The Earth Policy Institute (2010) stipulated that water tables all over the world are falling, as world water demand has tripled over the last 50 years. The developing countries are the once that are most affected by water shortages because of poor infrastructure and difficult living conditions. In Africa the problem of water shortages affect women directly, this is because women are seen as collectors, managers, and guardians of water, especially within the domestic sphere that includes household chores, cooking, washing, and child rearing (http://www.worldpulse.com/node/20165). Because of these traditional gender labor roles, women are forced to spend around sixty percent of their time each day collecting water which translates to approximately 200 million collective work hours by women globally per day (http://water.org/learn-about-the-water-crisis/women). For African women, this often means carrying the typical jerry-can that can weigh over 40 pounds when full for an average of six kilometers each day. As a result of this, many women are unable to hold professional employment.

Furthermore, water scarcity affects food security; this is because majority of Africa remains dependent on an agricultural lifestyle and so water scarcity translates to a loss of food security. Many African communities do not tap into their irrigation potential, and according to the UN Economic Commission for Africa and New Partnership for Africa's Development, irrigation is key to achieving increased agricultural production that is important for economic development and for attaining food security. Nevertheless, poor infrastructure and lack of well-developed technology exasperate the problem in most parts of Africa. Department of Water Affairs (2013) observed that water supply networks in the region are primarily asbestos cement with significant pipe bursts in certain areas due to the age of the infrastructure.

In Letaba catchment area bursting and leaking pipes are a common sight and hence, there is a high competition of water resources in the area. Communities in the urban areas in Tzaneen have advantage over rural communities. Wegelin, Zondo and Siqalaba (2013) identified the following challenges with regard to water supply in Letaba area:

- Limited support structures to aid reporting water related challenges

- Limited structural support for the improvement of services

- Limited training and capacity building to capacitate technical personnel

- Loss of water through illegal connections

Water management remains a problem at Letaba catchment area as the support systems are limited and the strategies that are used to manage water are not yielding much result. The catchment is characterized by "insufficient human capacity and skills to undertake all the technical work; skills are lacking at both management and technical work level" (Wegelin, Zondo and Siqalaba 2013:1). The lack of skills to manage water effectively has a negative impact on the equal access to clean water. Droughts, floods, and desertification are not as well handled well where skill is limited and these are a common occurrence these days due to climate change.

Furthermore, the Department of Water Affairs (2014) also observed that the relationship between Water South Africa and Letaba catchment area consumers is strained due to general dissatisfaction with the state of water services. This is due to the fact that onsumers are not engaged on water related issues and that there are no specific programmes that can help the communities to have an input in the development of water related policies. The community remains largely ill-informed regarding water conservation practices and other developments relating to water consumption. The water awareness campaign only gain momentum on specified dates such as Water week and other water related events. Thus, the consumer education on water conservation and management habitually become undertaken on ad-hoc basis.

\section{Conclusions}

Issues surrounding climate change contribute to a larger extent on water scarcity; therefore, there is a greater need for effective strategies that will ensure equal distribution and access to clean water. In Letaba catchment, water scarcity has increased competition amongst household and businesses. The competition has put a strain on the catchment. There is a need for well-trained managers and technical staff that will constantly develop mitigating factors against the climate change.

Water leakages, burst pipes and other water related queries should be given the necessary attention. This is because delays in attending water related queries mean more loss. Municipalities should also take it upon themselves to upgrade the water networks infrastructure and the related technology.

The public should be educated on water related issues and on what role can they play in conserving water. Water 
education should not only be conducted on the adhoc-basis but it should be an ongoing activity.

\section{Recommendations}

Water is being lost in the system through leaking and burst pipes. Therefore it is recommended that the Department of Water Affairs should develop monitoring strategies that will ensure that proper planning for water management take place. Officials responsible for technical operations of managing the water infrastructure should be constantly trained.

The general public should constantly be educated on the importance of preserving water; this exercise should not take place on ad-hoc basis as it is usually the norm. The community should also be involved when water related policies are developed. Ideally on-going water programmes should be developed as they will bring the water managers closer to the consumers.

Agricultural farmers should be encouraged to account for water that they use, other means of trapping water from the rainfall should be explored.

Municipalities should use supply side mechanisms to supply water to poor rural communities that do not have access to clean water until such time that permanent solutions are sought.

Centres dedicated to administering water related queries should be established.

\section{References}

Bless, C. Higson-Smith, C. \& Kagee, A. 2006. Fundamentals of Social Research: an African perspective, Fourth Edition, Juta \& Co. Ltd, Cape Town.

Comprehensive Assessment of Water Management in Agriculture. (2007). Water for food, water for life: A comprehensive assessment of water management in agriculture. London, UK: Earthscan; and Colombo, Sri Lanka; IWMI.

Earth Policy Institute. (2010). Sustainability and water. http://wwwoverpopulation.org/water-html.

Global Water Partnership. (2000). Integrated Water Resource Management (IWRM). TAC Background Papers No.4.

Herold,C.E. 2009. Des Midgley Memorial Lecture, The Water Crises in South Africa

Internal Strategic perspective, 2004. Luvuvhu/Letaba Water Management Area

Leedy, P.D. \& Ormond, J. E. 2014. Practical Research Planning and Design. 10th Ed. New Jersey: Pearson Merrill Prentice Hall.

Machete, E.M. 2011. The causes and impact of water shortage on the households of Ga-Kgapane Township in the Limpopo Province(Research submitted in partial fulfillment of the requirements for MBA, University of Limpopo).

Molewa,D (2013). Water resources are reeling under increasing pressure. http://www.savingwater.co.za/tag/water-scarcityl

Smits,S (2005) Well Factsheet: Water and livelihoods. http://www.Iboro.ac.uk/wellresources/fact-sheets-htm/water\%20and\%20live.htm

Stone, T. (2009). Water supply: Thinking strategically, IMIESA.

Van Vuuren, L. 2009. "The State off Water in South Africa - Are we heading for a Crisis?" The Water Wheel, Sept/Oct. pp.31-33.

Wegelin, WA, Zondo, N and Siqalaba, Z . (2013). Development of a reconciliation strategy for the Luvuvhu and Letaba water supply system: Water conservation and water demand strategy and business plan report. http://www.dwaf.gov.zalluvhuvhul Documentweb20\%DOC\%20CD2/WCWDM\%20strategy\%20\%20Business\%20PlanMopapipdf.

Websites browsed

(http://www.uneca.org/awich/Water\%20in\%20Africa.pdf

(http://thewaterproject.org/water_scarcity.asp.).

(http://water.org/learn-about-the-water-crisis/women

(http://www.worldpulse.com/node/20165).

http://www.dwaf.gov.za/rdm/documents/Briefing\%20Document.pdf 